Dorota Wolska

ORCID: 0000-0001-9851-1463

Uniwersytet Wrocławski

\title{
Ewa Kofin
}

Odo Marquard, niemiecki filozof, twierdził, że nikt nie żyje dostatecznie długo, by zdołał w pełni przekazać swoje rozumienie świata. Kiedy ktoś odchodzi, pozostawia i świat, i nas po części oniemiałych. Ostatecznie ubywa coś z rzeczywistości i nas samych. Reszta pozostaje na łasce kruszejącej pamięci.

W niedzielne południe, 21 lutego tego roku, odeszła Ew a Ko fin. Osoba wyjątkowa. Z jej obecnością kojarzy się nastrój życzliwego zainteresowania, empatii, delikatności, dyskrecji i taktu. Miała przymioty damy w najszlachetniejszym tego słowa znaczeniu. Świat Ewy Kofin stanowiła głównie muzyka w różnych jej wymiarach. Choć właśnie Jej zawdzięczam to, że słuchając, słyszę muzykę, to brakuje mi kompetencji, by oddać pełną sprawiedliwość Jej zasługom na polu teoretycznych rozważań o muzyce, dydaktyki w zakresie muzyki i muzykologii, krytyki muzycznej czy instytucjonalnego życia muzycznego. Ufam, że zrobią to Jej wierni i wdzięczni uczniowie, fachowi odbiorcy Jej książek, przedstawiciele rzeszy czytelników Jej recenzji drukowanych w specjalistycznej i codziennej prasie oraz last but not least urzędnicy miejscy.

Ewa Kofin związana była z innym jeszcze światem, dzięki czemu kolejny krąg ludzi miał przywilej Jej poznania i obcowania z tą niezwyczajną osobą. Jest to świat pionierski wrocławskiego kulturoznawstwa, z którym była związana od 1973 roku aż do końca swej długiej zawodowej aktywności. Trafiła tu, kiedy pozbawiono Ją, z powodów politycznych, funkcji dyrektorki szkoły muzycznej II stopnia w naszym mieście, pozostawiając bez środków do życia. Zaprosił Ją do współpracy założyciel studiów kulturoznawczych Profesor Stanisław Pietraszko. Żaden kulturoznawca początkowych i nieco późniejszych roczników nie wyobraża sobie studiów bez zajęć z Ewą Kofin: ciekawych, burzliwych dyskusji w oparach nikotynowego dymu (tak, wolno było palić na zajęciach w tamtych czasach. W pamięci pozostał mi duszący zapach tureckich czy albańskich tytoni). Dobro kulturoznawstwa jako kierunku studiów i dyscypliny badawczej zawsze leżało Ewie Kofin na sercu nie tylko z powodów sentymentalnych, lecz także dlatego, że ceniła poznawczą wartość tej perspektywy, a co warte podkreślenia, angażowała się wyłącznie w inicjatywy, do których była przekonana. Autentyczność, 
prawość oraz szczerość to ujmujące rysy Jej osobowości. Trudno nie pamiętać Jej wyjątkowej, niekłamanej radości z sukcesów innych: studentów i współpracowników. Rzecz coraz rzadziej dziś spotykana. Ewa Kofin z właściwą sobie rzetelnością i zapałem podjęła się na kulturoznawstwie badań fenomenów z pogranicza świata muzyki i kultury, czyniąc przedmiotem swych dociekań kulturę artystyczną, w tym szczególnie kulturę muzyczną, funkcjonowanie muzyki w obszarze kultury popularnej. Testowała także, powszechną od lat siedemdziesiątych w badaniach kultury, semiologię w jej możliwościach wyjaśnień i rozumienia sfery muzycznej.

Wiele jest powodów, by pamięć o Ewie pielęgnować. Jeden z nich wydaje mi się szczególnie ważny.

Otóż w pewnej sprawie Ewa Kofin, krucha, delikatna istota, w życiu codziennym niekiedy lękliwa, okazywała wielką siłę, determinację i zadziwiającą odwagę. Mianowicie nigdy nie spotkałam osobiście nikogo, kto żywiłby tak głęboką wiarę w sztukę i z równą siłą, bezkompromisowością bronił jej wartości na wszelkich możliwych polach. Nie była to na pewno postawa staroświecka, żadne dziewiętnastowieczne ubóstwienie sztuki. To raczej rodzaj szlachetnej misji, akt odpowiedzialności za coś, bez czego świat byłby uboższy i zdecydowanie gorszy.

Dziękuję losowi, że dał mi przywilej spotkania Ewy, a Jej dziękuję za dobry czas i przyjaźń.

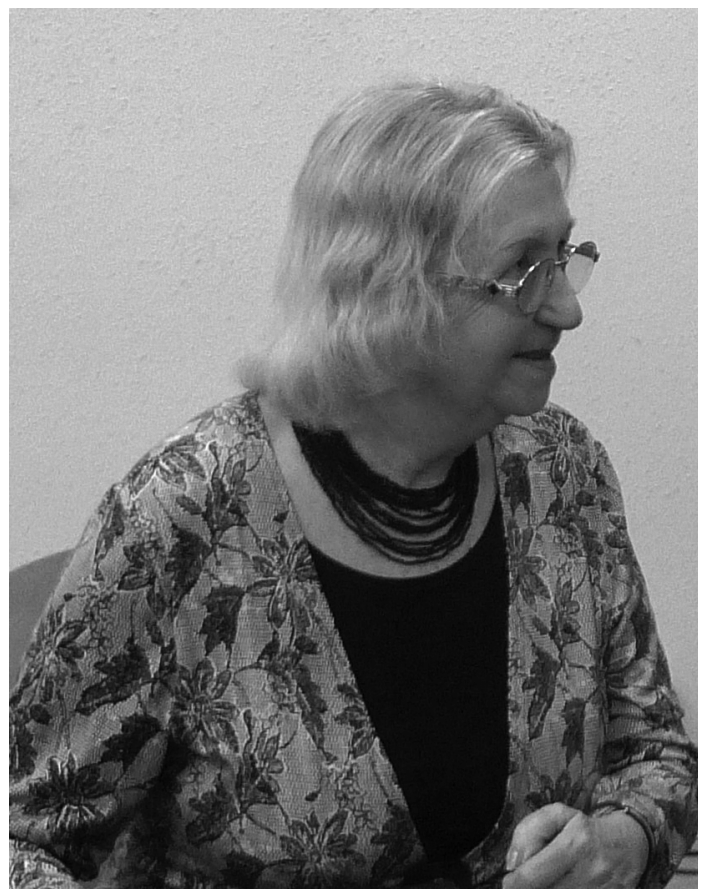

Ewa Kofin

Źródło: fot. Krzysztof Tańczuk. 